\title{
Dournal of Sharia Economics
}

Vol. 3, No. 1, June, 2021, pp. $64-75$

p-ISSN: 2655-2493 ; e-ISSN: 2655-2485

DOI: https://doi.org/10.35896/jse.v3i1.169

Website: http://journal.iaialhikmahtuban.ac.id/index.php/JSE

\section{Islamic Economics in the Middle of Civilization Transition}

\author{
Mohammad Ghozali1; Resi Handayani*.2; Wahyudi Bakri³ \\ ${ }^{1}$ Department of Islamic Economics, Faculty of Economics and Management, Universitas \\ Darussalam Gontor, 63471, INDONESIA \\ ${ }^{2}$ Department of Islamic Economics, Faculty of Economics and Management, Universitas \\ Darussalam Gontor, 63471, INDONESIA \\ ${ }^{3}$ Department of Islamic Economics, Faculty of Economics and Management, Universitas \\ Darussalam Gontor, 63471, INDONESIA \\ *Corresponding author, email: resihandayani.chichi@gmail.com
}

\section{A R T I C L E I N F O \\ Article history: \\ Received 24 January 2021 \\ Revised 30 April 2021 \\ Accepted 25 June 2021 \\ Available online \\ http://journal.iaialhikmah \\ tuban.ac.id/index.php/JSE \\ Keywords: \\ Capitalism Economic \\ System; \\ Socialism Economic \\ System; \\ Islamic Economic System.}

Turabian style in citing this article:

Ghozali, Mohammad., Resi Handayani, and Wahyudi Bakri " Islamic Economics in the Middle of Civilization Transition," Journal of Sharia Economics 3, no. 1 (June 2021): 64-75. 2021. https://doi.org/10.35896/ jse.v3i1.169

\section{A B S T R A C T}

The existence of an economic system of capitalism, an economic system of socialism, and an economic system of sharia are a response to problems regarding the economy as well as an answer to removing people from the obscurity of the existing economic system. It's hoped that these systems will be the key to the economic success of a society. But there are always advantages and disadvantages to every existing system. The economic system of capitalism is an economic system hi which investors or owners of capital are the movers and rulers. Meanwhile, the economic system of socialism is a system hi which the government is the main control, this system ignores the position of the individual, everything is regulated by the ruler and no one has the right other than the ruler. The considerations positives and negatives of each system have created a sharia economic system where this system has every positive side of the capitalist and socialist economic system but ignores the shortcomings or negative sides of the two systems. This paper discussed how the economic system of capitalism, the economic system of socialism, the Islamic economic system, and the relationship between them. The method used in this writing was library research, in which the authors used various secondary data from books, article, and many more. The results showed that it is clear that there are far differences between the conventional economic system and the Islamic economic system, the conventional economic system includes the economic system of capitalism and the economic system of socialism.

2021 Journal of Sharia Economics with CC BY SA license.

\section{INTRODUCTION}

Indirectly, there is a dichotomy of an economic system in people's lives, the most influential of which is the conventional economic system, including: the capitalist economic system, the socialist economic system, and until recently the Islamic economic system. This system exists as a response and solution to various problems in society. 


\section{Gournal of Sharia Economics}

Vol. 3, No. 1, June, 2021, pp. 64 - 75

Mohammad Ghozali; Resi Handayani; Wahyudi Bakri

Both in general and specifically, individually or in groups, macro, and micro.

Current development changes the economic system which increases according to the development of human culture. As homo economics, this is a human effort to complete their needs and survival. ${ }^{1}$ The economic system it's a group of economies that have regulations. Every economic institution influences each other for economic progress. $^{2}$ The discourse about Islamic economic system because recently began to find several weaknesses from the conventional economic system under the auspices of capitalism. Capitalism assumptions fail in realizing the original ideals of a common welfare economic system. ${ }^{3}$

Islam, as a heavenly religion that is complete and comprehensive but also universal, governs all aspects of human life, including the economy. Islamic economics actually has been born since Muhammad SAW started his career as a trader. Even though Islamic institutions had not yet emerged, Muhammad SAW had practiced a trading system that was later accommodated in Islam. Of course, the Islamic economy has different characteristics from others, including capitalism and socialism. ${ }^{4}$ There were some articles discussed about the Islamic Economics in the various context, for example related to the money and monetary in Islamic economics, ${ }^{5}$ also Islamic economics from the perspective of Maqasid Asy Syariah ${ }^{6}$, and many others. This paper discussed how the economic system of capitalism, the economic system of socialism, the Islamic economic system, and the relationship between them.

\section{LITERATURE REVIEW}

\section{Islamic Economics}

Islam is a teaching that concerns the entire system of life that is compressive, in which it regulates all aspects of life, both social, economic, cultural and political aspects, as well as spiritual matters as a form of servitude to God. In the economic context, Islamic teachings through the Qur'an and al-Sunnah are the main basis that establishes legal rules as limits for human behavior in carrying out economic activities aimed at achieving stability in the welfare of the people without having to be harmed by one of the parties. or only advantageous in one of the other parties. The Islamic economic system in it works based on (a) the same goal, it is seeking the satisfaction of various

\footnotetext{
${ }^{1}$ Syafiq Hanafi, Sistem Ekonomi Islam dan Kapitalisme, (Yogyakarta: Cakrawala, Cet. I, 2007), 1. 2M. Nur Rianto, Pengantar ekonomi Syariah Teori Dan Praktik, (Bandung: Pustaka Setia, Cet. 1, 2015), 63. ${ }^{3}$ Elma Muchtar Aditya, Universalitas Ekonomi Islam, Jumal Fokus Ekonomi, STEI Widya Manggala Semarang, Vol.3 No.l, Juni 2008, 87.

${ }^{4}$ Choirul Huda, Ekonomi Islam dan Kapitalisme (menurut Benih Kapitalisme dalam Ekonomi Islam), Economica: Jurnal Ekonomi Islam, Volume 7, Edisi 1, Mei 2016, 27

5 Joko Hadi Purnomo, "Uang Dan Moneter Dalam Sistem Keuangan Islam," Journal of Sharia Economics 1, no. 2, (December 2019): 80-100.

${ }^{6}$ Fira Mubayyinah, "Ekonomi Islam Dalam Perspektif Maqasid Asy-Syariah" Journal of Sharia Economics 1, no. 1, (June 2019): 14-29.
} 
needs of human life both for personal and public interests. The Islamic economic system works according to (b) the principle that is influenced and limited by Islamic teachings sourced from the Qur'an and hadith. ${ }^{7}$ Furthermore, Islamic economic system which is considered more fair, honest, and real has a completely different paradigm from the capitalist economy which prioritizes only one party, namely the owners of capital. Islamic economics is expected to provide a good and more rational alternative for the progress and welfare of the world community. ${ }^{8}$

According to Musa Asy'ari as quoted by Musran, in the Qur'an, economic principles emphasize the need for two basic principles, namely the existence of vertical dynamics in the form of work ethic and horizontal in the form of social welfare in economic life. In Islamic teachings, the behavior of individuals and communities is directed towards how to fulfill their needs and how to use existing resources. This is a subject that is studied in Islamic economics so that the economic implications that can be drawn from Islamic teachings are different from traditional economics. According to Metwally, the principles of Islamic economics can be broadly described as follows: ${ }^{9}$

1. In Islamic economics, various types of resources are seen as gifts or deposits from God given to humans. As a gift from God, humans as recipients of this gift must use it as efficiently and optimally as possible in production in order to fulfill common welfare in the world, namely for themselves and others. As a consequence, each of these activities will be accounted for in the hereafter.

2. Islam recognizes the existence of private ownership rights over certain goods within certain limits, including ownership of the means of production and factors of production. First, the right to individual ownership is limited and bound by the interests of the community, and second, Islam rejects and prohibits from any income earned illegally and void, let alone efforts to destroy society.

3. Islam realizes that cooperation is the main driving force of the Islamic economy. Consequently, for a Muslim, whether he is a buyer, seller, wage earner, or profit maker and so on, he must still adhere to the guidance of Allah swt in the Qur'an.

4. Private ownership of wealth must play a role as productive capital which will increase the amount of national product and improve the welfare of the community. Therefore, the Islamic economic system rejects the accumulation of wealth that is controlled by a few people. This concept is in stark contrast to the capitalist economic system, where industrial ownership is dominated by monopolies and oligopolies, including industry which is in the public interest.

5. Islam guarantees ownership rights for the community, and its use is planned for the benefit of the people. This principle is based on the Sunnah of the Prophet

\footnotetext{
${ }^{7}$ Ikit. Akuntansi Penghimpunan Dana Bank Syariah. (Yogyakarta: Deepublish, 2015)

8 Ikit. Akuntansi Penghimpunan Dana Bank Syariah. (Yogyakarta: Deepublish, 2015)

9 Yuliani. "KONSEP DAN PERAN STRATEGIS EKONOMI SYARIAH TERHADAP ISU KEMISKINAN" Iqtishadia 8, (1), March 2015: 133-154.
} 


\section{Gournal of Sharia Economics}

Vol. 3, No. 1, June, 2021, pp. 64 - 75

Mohammad Ghozali; Resi Handayani; Wahyudi Bakri

6. Islam teaches that a Muslim should be afraid of Allah and the hereafter.

7. In this regard, Islam denounces excessive profit taking, trade based on dishonesty, unfair treatment, all forms of discrimination and oppression.

8. A Muslim whose wealth exceeds a certain size (nis\}āb) is obliged to pay zakat. Zakat is a means of distribution of the wealth of the rich, which is shown to the poor and those in need.

9. Islamic teachings prohibit any interest payments (riba) on various forms of loans. Regarding the issue of flowers, the Qur'an gradually warns us about flowers

\section{METHOD}

This was a library research. Khatibah suggests library research as an activity carried out systematically to collect, process, and conclude data using certain methods/techniques in order to find answers to problems faced through library research. ${ }^{10}$ Meanwhile, Danandjaja suggests that library research is a systematic scientific method of bibliography research, which includes the collection of bibliographic materials, which are related to the research objectives; collection techniques with library methods; and organize and present data. ${ }^{11}$ The data used in this article was secondary data, in which the authors used various sources from books, research articles, website, and many more.

\section{RESULTS AND DISCUSSION}

\section{Capitalism Economy System}

Capitalism is the largest and most trusted economic system at a time where this system believes that the greatest power of economic movement is in the largest number of investors and the economic balance of various sectors is believed because of the existence of market mechanisms without government interference. The capitalist system is the power that is in the hands of every individual or individual, meaning that everyone can own resources and compete for profits. ${ }^{12}$

Capitalism comes from the origin of the word capital, which means capital, which is defined as a means of production such as land and money. Meanwhile, the word is means understanding or teaching. Capitalism is an economic system that tends towards being collected individually without interference from the kingdom or the government. It can be interpreted that capitalism is an understanding of the teachings of everything

\footnotetext{
${ }^{10}$ K. Khatibah Penelitian kepustakaan. Iqra': Jurnal Perpustakaan dan Informasi, 5(01), 2011: 36-39.

11 J. Danandjaja. Metode Penelitian Kepustakaan. (Indonesia: Antropologi Indonesia, 2014).

${ }^{12}$ Itang, Adib Damuri, Sistem Ekonomi Kapitalis, Sosialis dan Islam, Jurnal Keislaman, Kemasyarakatan dan Kebudayaan, Vol. 18, No. 1, 2017, 67
} 


\section{Gournal of Sharia Economics}

Vol. 3, No. 1, June, 2021, pp. 64 - 75

Mohammad Ghozali; Resi Handayani; Wahyudi Bakri

related to capital or money. ${ }^{13}$ In capitalist economy, the role of capital is very important. The owners of capital can control the market and determine prices in order to achieve large profits. Industrialization can run well through capitalism. ${ }^{14}$ The Definition of capitalism according to scientific:

1. According to Fernand Braudel, he said that "the capitalists are speculators and monopolists to obtain large profits without taking too much risk.

2. Capitalism by Karl Marx ${ }^{15}$ a production system based on the relationship between capital and labor. Investors have full rights regarding private ownership. Capitalism leads to individualism ownership in the realm of profit, the market system, etc.

3. Capitalism by Ayn Rand is "a social system based on the recognition of individual rights, including property rights, in which all property is privately owned". It's always about individualism.

4. According to Ebenstein, he is argument that capitalism as sistem comprehensive social and more than just an economic system. He linked the development of capitalism as part of the individualism movement. ${ }^{16}$

The capitalist economic system has the following principles:

1. There is freedom in owning material individually.

In the capitalist economic system, everyone has the authority to maximize their wealth. The theory applied by capitalism is carried out by monopolizing (ihtikar) and hoarding (iktinaz) in order to get as much profit as possible. ${ }^{17}$

2. Free Compition and Liberalism.

In the capitalist system, the free competition will be won by the strongest individual or group capable of controlling it entirely. This free competition can occur under any circumstances, between producers in producing products, between product distributors, between employees looking for employment, and so on.

3. Selfish.

Capitalism self-interest will automatically serve social interests. The assumption of self-interest is the main value in capitalism, where a person is considered to best understand his needs, wants and whatever is best for himself.

\footnotetext{
${ }^{13}$ Choirul Huda, Ekonomi Islam dan Kapitalisme (menurut benih Kapitalisme dalam Ekonomi Islam), 29. ${ }^{14}$ Yoshihara Kunio, Kapitalisme Semu Asia Tenggara, (Jakarta: LP3ES, Cet.1, 1990), 3

${ }^{15}$ The economist of capitalism. The youth came from a progressive Jewish family. His father, Herschel, is a descendant of the Rabis around the 19th century who is often called the father of communism, who came from scholars and politicians.

16 Siti Mujiatun, Peran Pemerintah Tentang Pengembangan Perekonomian Dalam Perspektif Sistem Ekonomi Kapitalis, Sosialis Dan Islam. Analytica Islamica, Vol. 3, No. 1, 2014, 93

${ }^{17}$ Rozalinda, Ekonomi Islam Teori dan Aplikasinya Pada Aktifitas Ekonomi, (Jakarta: Raja Grafindo Persada, 2014), 26
} 
4. Pricing mechanism.

In capitalism price determination comes from the market mechanism, the market system that will bring the welfare and prosperity of the whole society. The economy is the most efficient position in the market price mechanism process.

5. Lack of government role.

Every individual has the right to form and manage a company. With freedom in the management of a company, the state may not interfere in all economic activities. ${ }^{18}$ Capitalism has freedom characteristic because the balance economy is given to the full market mechanism.

Capitalism is considered a revolution that is fundamental in the formation of modem society. Today capitalism is not just an economic process, more than that, now the capitalist economic system has become a civilization that is rooted in ideology and then reflects a lifestyle. ${ }^{19}$ In other side, Capitalism becomes the main driver for technological change because capital accumulation is used to make new discoveries. It's known as classical capitalism ideology in Adam Smith's book ${ }^{20}$ with the main point on "laissez-faire"21 and invisible hand or market mechanism.

In a capitalist or liberal economic system, the individual is main role not the government. The government gives freedom to investors to develop their businesses. They can master and advance various aspects of the economy. The construction of roads, transportation, various government buildings, and other businesses are handled by the private sector. The government is responsible for making regulations to pay large taxes. The proceeds from the tax are used for the welfare of the people. ${ }^{22}$ Therefore, the competition be their estuary in various sectors that are: ${ }^{23}$

1. Financial sector, on basic the capitalism is greed, they created bank institutions and stocks as a way to quickly seize people's wealth.

2. General ownership sector. They create the mining sector, forest resources, and others in order to take common rights areas.

3. State ownership sector. The capitalists took the rights of state enterprises by supporting going public.

4. Power sector. This makes them want to have a sense of security in the existence of the company they have built so that they can bring out various legal products.

\footnotetext{
${ }^{18}$ Afzalurraham, Economic Doctrines of Islam terj. Soeroyo dan Nastangin, Doktrin Ekonomi Islam, (Yogyakarta: Darma Bakti Wakaf, 1995), 2.

${ }^{19}$ Agustiati, "Sistem Ekonomi kapitalisme", jurnal ACADEMICA, Vol 1, Oktober 2009, 164.

${ }^{20}$ Father of capitalism, his book was entitled The Wealth of Nations (1776). Reflects the ideology of thought and the rules of classical capitalism.

${ }^{21}$ Derived from French "laissez faire la nature" (let nature take its course), can be interpreted as an attitude of allowing freedom at will without regulation and control.

${ }^{22}$ Siti Mujiatun, Peran Pemerintah Tentang Pengembangan Perekonomian dalam perspektif sistem ekonomi kapitalis, sosialis dan Islam...97

${ }^{23}$ Supriyanto, Memahami Cara Bekeija Sistem Perekonomian, Jurnal Ekonomi Pendidikan, Vol. 6, 2009, 197
} 


\section{Gournal of Sharia Economics}

Vol. 3, No. 1, June, 2021, pp. 64 - 75 Mohammad Ghozali; Resi Handayani; Wahyudi Bakri

The advantages of the economic system of capitalism: ${ }^{24}$

1. Significantly encourage economic activity, because everyone tries to carry out the most efficient economic activity for himself and his group.

2. Freedom competition becomes a price level to a reasonable and rational position because everyone takes part in the competition. It will create a fair and rational price according to the circumstances.

3. Encourage economic perpetrator to occupy their best positions.

The disadvantages of the economic system of capitalism: ${ }^{25}$

1. Accumulation of assets between individuals and groups will lead to social inequality and unequal distribution of wealth among the people.

2. Lack of concern among members because this system prioritizes personal interests, the faction or group itself.

3. There is a distortion in moral values because everything is seen from economic aspects without emphasizing moral, ethical, or religious values. The impact is an unhealthy economy and fraud.

4. Conflicts between classes or between groups cause inequality and unequal distribution of wealth

\section{Socialism Economic System}

After the capitalist system continued with the socialism system. The birth of the socialist economic system is aimed at improving the suffering of the people due to the accumulation of capital in the economic system of capitalism, where the market mechanism is promised by the system. One of the most extreme forms of socialism is communism. Where economic decisions are made, planned, and controlled by the state at the same time.

Socialism assumes that good distribution is the action of the central democratic authority where the distribution is collective. The economic system is formed on the basis of the principle of togetherness. ${ }^{26}$ The spirit of socialism's rule is contrast to capitalism. Socialists put aside all personal rights for the common good. Their vision is the benefit together above the benefit of the individual. ${ }^{27}$

In the socialist economic system that always cares for common interests. ${ }^{28}$ The principles of the economic system of socialism are:

1. Equality

2. Private Property

3. Organize production and distribution collectively and are regulated under

\footnotetext{
${ }^{24}$ M. Nur Rianto Al Arif, Filosofi Dasar Ekonomi Islam, Modul 1, Ekonomi Islam, (Surakarta: Era Intermedia, 2011), 39

${ }^{26}$ Muhamad Umer chapra, Masa Depan Ilmu Ekonomi Islam Sebuah Tinjauan Islam (Jakarta: Gema insani Press, 2001), 112.

${ }^{27}$ Yusuf qordhawi, Norma dan Etika Ekonomi Islam, (Jakarta: Gema Insani Press, 1997), 70.

${ }^{28}$ Syamsuri, Ekonomi Pembangunan Islam, (Ponorogo: UNIDA Gontor Press, 2018), 35-36
} 
government supervision. ${ }^{29}$

It can be concluded that according to the socialist economic concept, this source of wealth is very scarce. It must be obtained through the empowerment of the workforce (laborers), in all fields, mining, agriculture, and others. In the Socialist system, all business fields are owned and produced by the State. The absence of a market and the absence of supply and demand, because the State provides all the needs of its people equally. The formulation of problems and decisions is handled directly by the state. ${ }^{30}$ The advantages of the socialism economic system: ${ }^{31}$

1. There is no unemployment because all of production machine are owned by the Stated.

2. Everyone has the opportunity to contribute work.

3. Everyone has the right to contribute the production process according to the talents and abilities.

4. There are no significant gaps among community members.

5. The government is easy to set market prices for goods and services.

The disadvantages of the economic system of socialism: ${ }^{32}$

1. Undermining or even killing individual initiative and creativity.

2. Often monopolistic practices are detrimental to society.

3. The community does not have the freedom to use existing resources.

\section{Sharia Economic System}

Islamic economics is an economy based on Islamic values. ${ }^{33}$ Such as the definition that Islamic economics is a social science that fix economics' problems which are inspired by Islamic values. ${ }^{34}$ Islamic economics is a knowledge that helps efforts to realize human happiness through the allocation and distribution of limited resources that are in the Islamic without limiting individual freedom to create a sustainable macroeconomic and ecological sustainable balance. ${ }^{35}$

Islamic economics reappeared because people began to realize some of the weaknesses that exist in the economic system of capitalism in realizing economic benefits, the emergence of economic injustice and large income inequality. As well as the monetary crisis in the economies of several countries in the world. Economic

\footnotetext{
29 Taqyuddin an nabhani, Membangun Sitem Ekonomi Alternatif Perspekti Islamk, (Surabaya: Risalah Gusti, 2008), 30; Mohammad Ghozali, Ekonomi Syariah Dalam Hegemoni Faham Kapitalisme Dan Sosialisme; Sebuah Solusi Pola Hidup Muslim, Ijtihad: Jurnal Hukum dan Ekonomi Islam Vol. 13, Edisi 1, 2019, 107-128

${ }^{30}$ Siti Mujiatun, Peran Pemerintah Tentang Pengembangan Perekonomian dalam perspektif sistem ekonomi kapitalis, sosialis dan Islam..., 97

${ }^{31}$ Delianov, Perkembangan Pemikiran Ekonomi, (Jakarta: PT.Raja Grafindo Persada, 1995), 84.

${ }^{32}$ Muhammad Tho'in, Konsep Ekonomi Islam Jalan Tengah (Kapitalis-Sosialis), Journal Ilmiah Ekonomi Islam, Vol. 01 No. 03, November 2015, 126

${ }^{33}$ M. Ismail Yusanto, M. Arif Yunus, Pengantar Ekonomi Islam, (Bantaijati: Al-Azhar Press, 2009), 12.

${ }^{34}$ Manan, Teori dan Praktik Ekonomi Islam, (Jakarta: Intermasa, 1992), 19

${ }^{35}$ Kadir Riyadi, Prinsip Dasar Ekonomi Islam, (Jakarta: Kencana, 2006), 3
} 
rationality ignores the moral dimension because of the many mistakes and mistakes in a number of economic activities. ${ }^{36}$

Everyone in this world as khalifah that given the Amanah to realize welfare as Islamic economic goal. To carrying out the Amanah must be in accordance with the concept of tazkiyah (height of morality). Tazkiyah concept will give rise to the concept of fallah, which is the key to success for everyone in this world and the hereafter. Therefore, realizing Fallah in economic activities must be based on justice and balance. ${ }^{37}$ The Islamic economic system is follows: ${ }^{38}$

1. To get Maslahah.

2. Do not extravagance.

3. Minimizing the risk.

4. Trying to complete the information to minimize risks.

The Islamic economic system is based on a religious worldview and vision, derived from the Qur'an and Hadith, which is different from the secular worldview and vision in conventional economic systems. The Islamic economic system relies on a profit and loss sharing system and prohibits usury, gharar (excessive speculation), and maysir (gambling) 39

\section{The Concept of Capitalism and Socialism in Sharia Economy}

Individual rights have the potential to create injustice and inequality and inequality in the distribution of wealth. This is done in the economic system of capitalism. But to abolish the human rights of every individual to the extreme as it is in the economic system, socialism is clearly contrary to human nature. The goal of improving the welfare of society is often carried out by ignoring or even eliminating individual considerations which are actually an important side of society itself.

In Islam, everyone is considered or viewed individually, not as an active group and living in a country. Individuals in Islam are humans, so they must fulfilled human's needs. Islam views every individual always sustainable and tied to each other in a relationship or interaction, with certain mechanisms according to customs and lifestyle. ${ }^{40}$ Therefore, everyone needs are always increasing and unlimited. Its reason that people always try to meet their needs and also try to work in completing their needs. This effort is human nature. With ownership rights, someone will try and work. ${ }^{41}$

\footnotetext{
${ }^{36}$ Elma Muchtar Aditya, Universalitas Ekonomi Islam, Jurnal Fokus Ekonomi, STEI Widya Manggala Semarang, Vol.3 No.l Juni 2008, 87.

${ }^{37}$ Syamsuri, Paradigma pembangunan ekonomi: Satu Analisis Tinjauan Ulang dari Perpektif Ekonomi Islam, Islamiconomic, Jumal Ekonomi Islam, Vol. 7, No. 2 Juli- Desember 2016, 236

${ }^{38}$ Mustafa Edwin Nasution, Penenalan Eksklusif Ekonomi Islam, (Jakarta: Prenada Media Group, 2007), 60; Anita Rahmawati, Ekonomi Makro Islam, (kudus: STAIN Kudus, 2009), 27-30

${ }^{39} \mathrm{Abu}$ Khaer, Paradigma Holistik Ekonomi Dalam Islam: Studi Perbandingan Dengan Kapitalisme dan Sosialisme, Jumal Ekonomi dan Keuangan Islam, Vol. 6, No. 2, 2017, 3

${ }^{40}$ Abdurahman Al-Maliki, Politik Ekonomi Islam, (Surabaya: Al-Izzah, 2001), 37.

${ }^{41}$ M. Abdul Mannan., Teori dan Praktek Ekonomi Islam, (Yogyakarta: Dana Bhakti Wakaf, 1993), 64
} 


\section{Gournal of Sharia Economics}

Vol. 3, No. 1, June, 2021, pp. 64 - 75

Mohammad Ghozali; Resi Handayani; Wahyudi Bakri

In fact, government authority in the socialism economic system is often involved by interests outside the realm of the economy, for example politics controlled by the government. Social rights take precedence but ignore individual rights. ${ }^{42}$ On the other hand, it has the potential to improve the distribution of income and wealth but also creates a sense of injustice and neglects economic efficiency.

The Islamic economic system is different from the capitalist and socialist economic systems; and some ways are contradiction between of them. The Islamic economic system has the virtues of the capitalist and socialist economic systems but ignores the weaknesses of both systems.

Relationships between individuals in the Islamic economic system are structured then build mutual help and cooperation. This avoids competition and hostility among individuals. For this purpose, the Islamic economic system not only provides individuals with convenience in the economic and social fields but provides them with moral education and certain exercises that make them feel responsible for helping colleagues in achieving their desires or at least not hindering them in their efforts to live. ${ }^{43}$

\section{CONCLUSION}

From the above discussion, it is clear that there are far differences between the conventional economic system and the Islamic economic system, the conventional economic system includes the economic system of capitalism and the economic system of socialism. The capitalist economic system prioritizes and prioritizes individuals or individuals while the socialist economic system prioritizes groups or the wider community. The Islamic economic system can balance the two systems by taking advantage of all the advantages of both and ignoring the weaknesses of both. The Islamic economic system acts as an intermediary to provide fresh air for people trapped in these two systems, give breath to individuals who are suffocated as a result of the defilement of the capitalist and socialist economic system. The Islamic economic system is all values that are based on all beliefs and will become the foundation of the Islamic economic paradigm. These values include philosophical, instrumental comprehensively, and universally.

\footnotetext{
42 Ambok Pangiuk, Kepemilikan Ekonomi Kapitalis dan Sosialis (Konsep Tauhid dalam Sistem Islam), Jumal Kajian Ekonomi Islam dan Kemasyarakatan: NALAR EIQIH, Vol 4, No 2, December 2011, 7

${ }^{43}$ Afzalur Rahman, Doktrin Ekonomi Islam, terj. Soerojo dan Nastangin, (Yogyakarta: Dana Bhakti Wakaf, Jilid I, 1995), 10
} 


\section{REFERENCES}

Aditya, Elma Muchtar, "Universalitas Ekonomi Islam”, Jurnal Fokus Ekonomi STEI Widya Manggala Semarang 3, no. 1 (June 2008).

Agustiati, "Sistem Ekonomi kapitalisme”, Jurnal Academica l, no. 2, (Oktober 2009)

Al-Maliki, Abdurrahman, Politik Ekonomi Islam, Bangil: Al-Izzah. Diterjemahkan oleh Ibnu Sholah, Surabaya: Al-Izzah, 2000.

An-Nabhani, Taqyuddin, Membangun Sitem ekonomi Alternatif Perspekti Islam, Surabaya: Risalah Gusti, 2008.

Chapra, Mumahhmad Umer, Masa Depan Ilmu Ekonomi Islam Sebuah Tinjauan Islam Jakarta: Gema insani Press, 2001.

Deliamov, Perkembangan Pemikiran Ekonomi, Jakarta, PT.Raja Grafindo Persada, 1995.

Hanafi, Syafiq, Sistem Ekonomi Islam dan Kapitalisme, Yogyakarta : Cakrawala, Cet. 1, 2007.

Huda, Choirul, "Ekonomi Islam Dan Kapitalisme (Merunut Benih Kapitalisme dalam Ekonomi Islam", Jurnal Economica 7, no. 1, (Mei 2016).

Ikit. Akuntansi Penghimpunan Dana Bank Syariah. (Yogyakarta: Deepublish, 2015)

Itang, Adib Darnuri, "Sistem Ekonomi Kapitalis, Sosialis dan Islam”, Jurnal Keislaman, Kemasyarakatan dan Kebudayaan 18, no. 1, 2017.

Khaer, Abu, Paradigma Holistik Ekonomi Dalam Islam: Studi Perbandingan Dengan Kapitalisme dan Sosialisme, Jurnal Ekonomi dan Keuangan Islam Vol. 6, No. 2, 2017

Khatibah, K. Penelitian kepustakaan. Iqra': Jurnal Perpustakaan dan Informasi,, 5(01), 2011: 36-39.

Kunio, Yoshihara, Kapitalisme Semu Asia Tenggara, Jakarta: LP3ES, 1990.

Manan, Muhammad Abdul, Teori dan Praktik Ekonomi Islam, Jakarta: Intermasa, 1992.

Mannan, M. Abdul, Teori dan Praktek Ekonomi Islam, Yogyakarta: Dana Bhakti Wakaf, 1993.

Mohammad Ghozali, "Ekonomi Syariah Dalam Hegemoni Faham Kapitalisme Dan Sosialisme; Sebuah Solusi Pola Hidup Muslim", Ijtihad: Jurnal Hukum dan Ekonomi Islam 13, no. 1, (2019).

Mubayyinah, Fira. "Ekonomi Islam Dalam Perspektif Maqasid Asy-Syariah" Journal of Sharia Economics 1, no. 1, (June 2019): 14-29.

Mujiatun, Siti, "Peran Pemerintah Tentang Pengembangan Perekonomian dalam Perspektif Sistem Ekonomi Kapitalis, Sosialis dan Islam." Analytica Islamica 3, no. 1, (2014).

Nasution, Mustafa Edwin, Penenalan Eksklusif Ekonomi Islam, Jakarta: Prenada Media Group, 2007.

Pangiuk, Ambok, "Kepemilikan Ekonomi Kapitalis dan Sosialis (Konsep Tauhid dalam Sistem Islam)," Jurnal Kajian Ekonomi Islam dan Kemasyarakatan: NALAR FIQIH 4, no. 2, (Desember 2001).

Purnomo, Joko Hadi. "Uang Dan Moneter Dalam Sistem Keuangan Islam," Journal of 


\section{Gournal of Sharia Economics}

Vol. 3, No. 1, June, 2021, pp. 64 - 75 Mohammad Ghozali; Resi Handayani; Wahyudi Bakri

Sharia Economics 1, no. 2, (December 2019): 80-100.

Qordhawi, Yusuf, Norma dan Etika Ekonomi Islam, Jakarta: Gema Insani Press, 1997.

Rahman, Afzalur, Doktrin Ekonomi Islam, terj. Soerojo dan Nastangin, Yogyakarta: Dana Bhakti Wakaf, Jilid 1, 1995.

Rahmawati, Anita, Ekonomi Makro Islam, Kudus: STAIN Kudus, 2009.

Rianto Al Arif, M. Nur, Filosofi Dasar Ekonomi Islam, Modul 1, Ekonomi Islam. Surakarta: Era Intermedia, 2011.

Rianto Al Arif, M. Nur, Pengantar ekonomi Syariah Teori Dan Praktik, Bandung: Pustaka Setia, 2015.

Rivai, Veitzal dan Andi Buchari, Islamic Economics: Ekonomi Syariah Bukan Opsi Tetapi Solusi, Jakarta: Bumi Aksara, 2009

Riyadi, Kadir, Prinsip Dasar Ekonomi Islam, Jakarta: Kencana, 2006.

Rozalinda, Ekonomi Islam Teori dan Aplikasinya Pada Aktifitas Ekonomi, Jakarta:Raja Grafindo Persada, 2014.

Supriyanto, Memahami Cara Bekeija Sistem Perekonomian, Jurnal Ekonomi Pendidikan 6, no. 2, (2009)

Syamsuri, Ekonomi Pembangunan Islam, (Ponorogo: UNIDA Gontor Press, 2018)

Syamsuri, Paradigma Pembangunan Ekonomi: Satu Analisis Tinjauan Ulang dari Perpektif Ekonomi Islam, Islamiconomic, Jurnal Ekonomi Islam, Vol. 7, No. 2 JuliDesember, 2016.

Tho'in, Muhammad, Konsep Ekonomi Islam Jalan Tengan (Kapitalis-Sosialis), Jurnal Ilmiah Ekonomi Islam Vol. 01 No. 03, November 2011

Waluyo, Agus, Ekonomi Konvesional VS Ekonomi Syariah, (Yogyakarta: Ekuilibria, 2017)

Yuliani. "KONSEP DAN PERAN STRATEGIS EKONOMI SYARIAH TERHADAP ISU KEMISKINAN" Iqtishadia 8, (1), March 2015: 133-154.

Yusanto, M. Ismail, M. Arif Yunus, Pengantar Ekonomi Islam, (Bantaijati: Al-Azhar Press, 2009) 